\title{
Becoming a Vertebrate Palaeontologist
}

\section{Turner $\mathrm{S}^{*}$}

Department of Geosciences, Queensland Museum, Australia

Mini Review

Volume 4 Issue 1

Received Date: January 27, 2021

*Corresponding author: Susan Turner, Honorary Research Fellow, Department of Geosciences, Queensland Museum, 122 Gerler Road, Hendra, Queensland 4011, Australia, Email: sue.turner@qm.qld.gov.au ; paleodeadfish@yahoo.com

\section{Abstract}

The roads to becoming a palaeontologist or contributing to the discipline are many and varied and for women, often tortuous. Concentrating on early to mid $20^{\text {th }}$ century women in Europe brings to light some of the ways in which women survived in the field of vertebrate palaeontology (VP) studying from the earliest fish to our own human relatives. Only are few are known: e.g., in Britain (Pearson, Steen, Rayner), France (Friant, Dechaseaux), Germany (Edinger, von Huene), Hungary (Mottl), The Netherlands (Schreuder, Sanders,), Romania (von Nopsca), and Sweden (Carlsson, Christie-Lind). It is not always easy to unravel the whys and hows of their scientific contributions or even the basic details of their lives but new historical research has brought to light over 1200 women in VP. Their paths to contributing to VP and the difficulties overcome add to the history of women in science and may inspire others to choose a life in Science, Technology, Engineering and Mathematics (STEM).

Keywords: Vertebrate Palaeontology; Women; Historical Research; STEM; 20th Century; Western Europe

Abbreviations: STEM: Science, Technology, Engineering and Mathematics; VP: Vertebrate Palaeontology; SVP: Society of Vertebrate Paleontology; DMS: David Meredith Seares; UCL: University College London; MNHN: Museum National d'Histoire Naturelle; NHM = The Natural History Museum

\section{Introduction}

Investigating the history of women in science meets the challenges of unravelling the lives of people who are mainly 'missing' from the narratives of life [1,2]. Both Oldroyd [3] and Falk [4] have pinpointed the difficulties especially when dealing with more recent history. Delving into any history of science text will not enlighten you too much on which women hunted for mammoths or dinosaurs. In fact, few women before the last decade or so even wrote about the history of science. One who did, Emily Eveleth Snyder [5], science teacher of Little Falls, New York, could only find one woman who had contributed, as an artist - the illustrative skills of young Cecile Braun of Karlsruhe (born anywhere between 1799 \& 1810?-1848), who captured the eye (and eventually the heart) of pioneer palaeoichthyologist Louis Agassiz [6].
Over the last three years, Annalisa Berta, Professor Emerita at San Diego State University and the author cooperated to create a first definitive history of women in VP, with over 1200 noted for their contributions. In our new book [6], we have considered the stories of discovery, collection, and study and popularisation of fossil vertebrates by women. Our goal was to highlight the changing roles through time and increasing contributions by women around the world, both as professional scientists and 'amateurs'. In our quest, we interviewed and corresponded with many of the currently active women and tracked the lives of the many, some forgotten, women of the past.

Because in much of the world the same constraints apply, despite efforts such as the UN programmes to educate young women, and in certain places girls are still forbidden education, we need to foster an attitude of encouraging young people into STEM. Collecting fossils is one way that anyone can enter the field, as we rely on amateurs to make special finds. Based on numerous examples, from Mary Anning of Lyme Regis on, children are particularly good at finding fossils, being closer to the ground and with their keen 


\section{International Journal of Paleobiology \& Paleontology}

young eyes. Thus, here I'd like to highlight some of those women who freed themselves, by education and entered the scientific VP arena in the early $20^{\text {th }}$ century. I shall concentrate on the area we call Europe (ignoring Brexit) and on a few key contributors. For more see [6] and Table 1.

\begin{tabular}{|c|c|c|c|c|c|c|c|}
\hline Name & Dates & Place of birth & Training & Job/Research & Relationships & Pubs & Refs \\
\hline $\begin{array}{c}\text { Karoline } \\
\text { ADAMETZ 'Lotte' }\end{array}$ & $1879-1966$ & Austria & $\begin{array}{l}\text { commercial } \\
\text { school; } \\
\text { self-taught }\end{array}$ & $\begin{array}{c}\text { Curation, } \\
\text { Mammals; field } \\
\text { work; photography }\end{array}$ & $\begin{array}{c}\text { 1898-Secretary, } \\
\text { G-P, NH Mus }\end{array}$ & $\sim 10$ & Obit \\
\hline $\begin{array}{l}\text { Augusta Ärnbäck } \\
\text {-CHRISTIE-LIND } \\
\text { (nee Andersson }\end{array}$ & $1870-1953$ & Sweden & $\begin{array}{c}\text { Self-taught } \\
1909 \mathrm{PhD}\end{array}$ & M & & $\sim 9$ & BFV \\
\hline Virginia BARBU & 1905-1997 & $\begin{array}{c}\text { Romania } \\
\text { SSR }\end{array}$ & $\mathrm{PhD}$ & $J F$ & & $\begin{array}{l}\sim< \\
10 \\
\end{array}$ & $\mathrm{BFV}$ \\
\hline Dorothy BATE & $1878-1951$ & Wales & self-taught & $\begin{array}{c}\text { Curation, } \\
\text { Mammals; field } \\
\text { work }\end{array}$ & $\begin{array}{l}\text { Director Tring } \\
\text { Museum }\end{array}$ & $\sim 56$ & $\begin{array}{c}\text { Shindler } \\
2004\end{array}$ \\
\hline $\begin{array}{c}\text { Albertina } \\
\text { CARLSSON }\end{array}$ & $1848-1930$ & Sweden & $\begin{array}{c}\text { Hon. } \mathrm{PhD} \\
1927\end{array}$ & $\mathrm{M}$ & $\begin{array}{c}\text { Stockholm } \\
\text { teacher }\end{array}$ & $\sim 30$ & \\
\hline $\begin{array}{c}\text { Elsie Margaret } \\
\text { CLIFFORD }\end{array}$ & $1885-1976$ & England & & $\begin{array}{c}\text { Zooarchaeo } \\
\text { Q M }\end{array}$ & & & \begin{tabular}{|c|} 
Tomlinson \\
1941 \\
\end{tabular} \\
\hline $\begin{array}{c}\text { Colette } \\
\text { DECHASEAUX } \\
\end{array}$ & 1906-1999 & France & $\mathrm{PhD}$ & $\begin{array}{c}\text { Palaeoneurology } \\
\text { R B M }\end{array}$ & MNHN & $6+$ & $\mathrm{BFV}$ \\
\hline Tilly EDINGER & 1897- 1967 & Germany & $\mathrm{PhD}$ & paleoneurology & $\begin{array}{c}\text { Senckenberg } \\
\text { until } 1938\end{array}$ & $>400$ & Obit; BFV \\
\hline $\begin{array}{l}\text { Madeleine } \\
\text { FRIANT }\end{array}$ & $\begin{array}{c}1897- \\
197 / 8 x ?\end{array}$ & France & $\mathrm{PhD}$ & M & MNHN & $\sim 90$ & $\mathrm{BFV}$ \\
\hline Erika von HUENE & $1905-1969$ & Germany & $\mathrm{PhD}$ & JF, R M & $\begin{array}{l}\text { Friedrich von } \\
\text { Huene }\end{array}$ & $\sim 8$ & \\
\hline $\begin{array}{l}\text { Miss A.C. } \\
\text { JACKSON }\end{array}$ & 19xx?-dates? & Scotland? & & $\begin{array}{c}\text { JF coll. - ORS } \\
\text { Edderton Burn }\end{array}$ & $?$ & $\mathrm{n} / \mathrm{a}$ & $\begin{array}{c}\text { Cleevely } \\
1983 \\
\end{array}$ \\
\hline Maria MOTTL & $1906-1980$ & Hungary & $\mathrm{PhD}$ & M & $\begin{array}{c}\text { Budapest } \\
\text { Mr Györffy }\end{array}$ & $\sim 70$ & Obit; BFV \\
\hline $\begin{array}{c}\text { Ilona } \\
\text { NOPCSA von } \\
\text { FELSOE-SZILVAS }\end{array}$ & $1883-1952$ & Romania & & Dinosaur bones & $\begin{array}{l}\text { Elder Brother } \\
\text { Franz Freiherr } \\
\text { von Nopsca }\end{array}$ & & \\
\hline Helga PEARSON & $1899-1975$ & England & 1927 DSc & R M & $\begin{array}{c}\text { DMS Watson } \\
\text { Mr Hacker }\end{array}$ & $\sim 8$ & \\
\hline $\begin{array}{c}\text { Dorothy Helen } \\
\text { RAYNER }\end{array}$ & $1912-2003$ & England & $\mathrm{PhD}$ & $\mathrm{JF}$ & DMS Watson & & $\begin{array}{c}\text { Boylan } \\
2020 \\
\end{array}$ \\
\hline $\begin{array}{l}\text { Margarethe } \\
\text { SANDERS }\end{array}$ & $1905-1996$ & $\begin{array}{l}\text { The } \\
\text { Netherlands }\end{array}$ & $\mathrm{PhD}$ & $\begin{array}{c}\text { Unpaid incl. Leiden } \\
\text { Naturalis; Shell } \\
\text { consultant }\end{array}$ & $\begin{array}{l}\text { Mrs L. D. } \\
\text { Brongersma }\end{array}$ & $\sim 40$ & bio \\
\hline $\begin{array}{c}\text { Antje } \\
\text { SCHREUDER } \\
\end{array}$ & $1887-1952$ & Dutch & $\mathrm{PhD}$ & M & & $\sim 50$ & Obit; BFV \\
\hline $\begin{array}{l}\text { Margaret C. } \\
\text { STEEN }\end{array}$ & 1905- 1971 & England & $\mathrm{PhD}$ & $\mathrm{T}$ & $\begin{array}{c}\text { Mrs James } \\
\text { Brough } \\
\text { DMS Watson }\end{array}$ & $\sim 6$ & BFV \\
\hline
\end{tabular}

Table 1: European Women in VP in the Late $19^{\text {th }}$-mid $20^{\text {th }}$ century.

For more see Berta \& Turner [6] and literature cited; BFV = Bibliography of Fossil Vertebrates; B = birds, JF = jawed fishes, R = reptiles, $\mathrm{M}=$ mammals, $\mathrm{NH}=$ natural history, $\mathrm{Q}=$ Quaternary, $\mathrm{ORS}=$ Old Red Sandstone, $\mathrm{T}=$ tetrapods. 


\section{International Journal of Paleobiology \& Paleontology}

\section{Early History}

Few women before the later $20^{\text {th }}$ to $21^{\text {st }}$ centuries made a life in science or gained formal paid positions. For the most part women were overwhelmed with social, domestic and biological constraints. Those that have achieved recognition in the bio- and geosciences for their roles in palaeontology do not constitute many (e.g., Kölbl-Ebert \& Turner [2]). In recent decades the lives of the few in the $19^{\text {th }}$ century who contributed to VP have been illuminated, with long-overdue pride in those pioneers, such as Mary Anning, Etheldred Bennet, and the Philpot sisters in England, Fanny Hitchcock and Carrie Adeleine Barbour in America, who had actually gained a paid position in the Nebraska-Lincoln University State Museum in the late $19^{\text {th }}$ century, Anna Boleslavovna Missuna in the Baltics, and Maria Pavlova in Russia, who trained in France (e.g. Berta \& Turner [6]). In the $18^{\text {th }}$ and $19^{\text {th }}$ centuries the women were mainly confined to Britain, parts of Europe and the US and few got a paid job! Most young girls or women could have no aspirations because education and opportunities were lacking. This is why Mary Anning's life is so remarkable (e.g. Sharpe [7]).

Minds did change, not least after Darwin's 1859 publication of the Origin of Species; women's emancipation increased by the end of the $19^{\text {th }}$ century and slowly barriers fell. A major factor in finally encouraging women into the discipline was the coming of societies that they could belong to, and for VP this means the Society of Vertebrate Paleontology (SVP), founded eventually in December 1940. The role of women in the early SVP has mostly been neglected. In the course of research for the new book, we 'discovered' over 25 female founding or 'Charter' members. Most were American, including the then indefatigable septuagenarian Carrie Barbour, but also the resilient European-born Tilly Edinger (see below) and Lore David (1905-1985), both of whom escaped the Nazi regime [6].

\section{$20^{\text {th }}$ Century Europe}

At this time, the western world women were gaining the vote, first in the southern hemisphere and then in the US and UK and around Western Europe. By the end of the $19^{\text {th }}$ century universities were opening up to women. However, there are still relatively few women scientists able to pursue a research career; usually they lost their jobs when they decided to marry. During this time two major world warsWWI 1914-18 and the aftermath 'Spanish' flu pandemic that followed and WWII 1939-45-disrupted education, and ambitions were changed for many; some women benefitted from the massive loss of life in these conflagrations and new possibilities ensued.

\section{Albion's Best}

By the end of the $19^{\text {th }}$ century more women began to gain education, independence and even university degrees were possible. They began to gain employment, and for these more intrepid women field collecting was undertaken in earnest. In Britain, Welsh-born Dorothea Bate, who talked her way into employment at the British Museum of Natural History in London (now NHM), albeit in an unpaid position, went on to excavate mammal and bird fossils from numerous sites in Europe and the Middle East. Fortunately, she gained a biographer in historian Karolyn Schindler [8].

Three other important British women came to the fore in the suffragette era and thanks to the influence of David Meredith Seares (DMS) Watson at University College London (Department of Zoology, UCL), and they shined in VP. From an impeccable academic family that encouraged freethinking, Helga Sharpe Pearson, daughter of UCL biostatician Karl Pearson, who wrote The Grammar of Science. In 1921 after her B.Sc., became Assistant in UCL Zoology and began research on fossil mammals. Helga went to visit the US to study fossils, starting a trend that continues today as collections are located in institutions around the world. In the early 1920s she then did important work and published on South African dicynodont mammal-like reptiles.

At the behest of DMS, Margaret Clair Steen became the first woman to work on early Carboniferous tetrapods. After early training with him at UCL, she gained her doctorate at Victoria University Manchester. Her significant body of work in the 1930s on US, UK and Czech amphibians laid the foundation for the successful Newcastle University Alec Panchen School later in the $20^{\text {th }}$ century [6]. Marriage to fellow DMS-student James Brough did not stop her research completely and when he became Chair of Zoology at Cardiff University in 1944, the university happily also 'acquired' Margaret virtually by default. The running of a family did put her scientific life on hold for many years and two decades passed before her final paper.

Dorothy Helen Rayner also had DMS as her most influential research mentor, working jawed Mesozoic fishes, going on to an important university career, stepping into a post during early WWII and training many paleontologists for the next 3-4 decades. From a well-off family with a tradition in science and an unconventional schooling at 'progressive' Bedales School, Dorothy was one of the first women to be appointed to a tenured academic post in any English geology department, joining Geology at Leeds as Assistant lecturer in 1939. In 1919, long after other leading universities, Cambridge finally established the Doctor of Philosophy (PhD) and her father Edwin Rayner was one of 


\section{International Journal of Paleobiology \& Paleontology}

the first to gain his; Boylan [9] considered that this was a major spur to Dorothys life choices. In addition, her mother Agnes, nee Styles, was an active suffragette. Dorothy's time at Cambridge in 1933-35 expanded her love of palaeontology; she joined the undergraduate student Sedgwick Club and gained a First at Girton College in the Cambridge Natural Sciences Tripos. Her ground-breaking research on Jurassic fishes, led to the award of a Cambridge PhD in 1938 [9]. By modern-day standards her output was not voluminous but each paper was significant in so-called 'top' journals. She travelled to study collections in the States and Sweden and undertook field work at the Devonian fish quarries at Achannaras, Scotland. Dorothy made a major review of Upper Paleozoic and Mesozoic geological environments of fossil fishes and joined others brought together by fellow student and close friend T. Stanley Westoll to produce a Festschrift for DMS on his retirement [10]. Her research output suffered in relation to her teaching load but she went on to write two major textbooks and the Geological Society of London finally recognized her in 1975 with the award of the prestigious Lyell Medal, a rare event for a woman [9].

\section{France}

Madeline Friant has the distinction of being the first French woman to undertake VP research and to attain a high position at the Museum National d'Histoire Naturelle (MNHN) in Paris. She was contemporary with Pearson and Bate and did visit Britain for research, signing Lady Maud Woodward's famous tablecloth [11]. After her earlier medical training and research gaining her doctorate in natural sciences, she became a comparative anatomist at the MNHN and a Chargée de recherche of the future CNRS. She began to work on the dentary evolution of the castorids. She researched many groups from amphibians, birds and several mammals including cave bears, elephants, and rodents to whales. In 1937 aged 40, she succeeded to the sub-directorship of Comparative anatomy of the museum. Friant's story is incomplete, because, like many others, as yet we have found no obituary for Madeleine. Interestingly, P.J. Erb noted [12] that "She leaves the memory of an energetic woman, known for her strong character who sometimes alienated the sympathies of her colleagues." I wonder if he would have said the latter of male bosses?

Friant's compatriot Colette Dechaseaux trained later and first as an invertebrate palaeontologist, coming later to VP and a job at MNHN. She began her work in the 1930s inspired to study palaeoneurology by Edinger's example. They began to correspond and Tilly encouraged her later to 'finish her work'. Without her the 1950s to 60s Traité de Paléontologie would not have come to fruition.

\section{Germany}

Few German women had scientific careers. The first woman to gain a biological $\mathrm{PhD}$ at a German university was Tilly Edinger, who was fortunate to grow up in an intellectual Jewish family in Frankfurt with a father, a neurobiologist, who believed in education. She spent her early working life at the Senckenberg Museum, initially in an unpaid position, where she began her landmark study of vertebrate fossil brains, and in so doing she founded the field of paleoneurology with a major review in 1929. Her mentors were Friedrich von Huene in Tuebinen and Belgian Louis Dollo. Tilly narrowly escaped Nazi persecution in 1938-9, and in her early 40s left her home first to England and then gained a place in the US, later becoming the first women president of the SVP in 1964 [6].

Her slightly younger contemporary, Erika von Huene had a very different upbringing in her father's Pietist household but she too was trained and inspired by Friedrich von Huene. Erika did pioneering work on Rhaetic bonebeds and early mammals but she too fell foul of the Nazi regime as she gained her doctorate in April 1933 as Hitler came to power and then had to struggle to gain work. Helped by colleagues she managed to continue for a few years researching many Mesozoic reptiles from Germany but both WWII and its aftermath defeated her and she gave up her scientific life.

\section{Hungary}

Maria Mottl was a geologist and pioneer VP in Hungary, with an impressive oeuvre over four decades encompassing work particularly on Quaternary cave faunas. Born in Budapest to an established family, her life reflects the ebb and flow of European history at this time. She studied at the universities of Vienna, Berlin and Budapest and gained her doctorate summa cum laude from University of Budapest. Her first employment was at the Royal Hungarian Geological Institute and, like von Huene, she begins to publish in 1933 getting interested in cave bears through her speleogical studies. She corresponded with both Bate (NHM) and Schreuder (Leiden Naturalis) on Pleistocene mammals. Following the rise of Hitler and resulting changes, she moved to Austria and was based at the Joanneum Museum in Graz. This move might have been related to her background or because of marriage; by 1942 she is noted as Györffy-Mottl [1] and her devotion to family (but how many children?) was acknowledged in her memorials. In the aftermath of war, she helped rebuild the shattered Austrian economy with her knowledge of cave geology, working at the Federal Monuments Office, going on to excavate the 100,000-yr old cave Repolust in 1947-8. This extended her interest in prehistoric and end Ice Age faunas and human activity. 


\section{International Journal of Paleobiology \& Paleontology}

\section{The Netherlands}

Holland had not encouraged many women into paleontology but two important scientists span the early $20^{\text {th }}$ century [6]. It is nearly 70 years since pioneer Dutch palaeontologist Antje 'Annie' Schreuder died in The Netherlands. She became a specialist in fossil small mammals such as water-moles (desmanids) and achieved a significant ouvre over 4 decades. Studying at the prestigious University of Amsterdam, like so many, her life was put on hold during WWI and the aftermath. She resumed her research in 1923 gaining her doctorate five years later. She soon became the acknowledged authority in Western Europe on Quaternary mammalian bone remains.

Following Schreuder as research assistant to Eugene Dubois at Amsterdam University in 1929 (e.g. Shipman [13]), the subsequent VP work of Margaretha 'Greet' BrongersmaSanders received almost no international recognition until well after her death. Her work to unravel the taphonomy of fish fossilisation and mass mortalities of the sea was pivotal in the origins of geochemistry and understanding of the origins of oil. Sanders came also from an academic family and from her earliest days she wanted to be a scientist. After gaining her highly acclaimed doctorate on Tertiary fishes from Indonesia from Amsterdam University in 1934, she visited Africa with her new husband and witnessed the massive fish kill on the Namibian coastline during her honeymoon. Greet realised the significance and went on to write her pivotal papers. Although she was based in the university and Leiden Natural History museum she did not get paid but she made good use of the terrifying WWII years in researching fish kills globally from the literature. After the war, she was headhunted by Royal Shell and became a consultant and pioneer in organic geochemistry, especially investigating black shales [6].

\section{Sweden}

Two Swedish women made early contributions to VP although they were trained in zoology and comparative anatomy, both trained in the late $19^{\text {th }}$ to early $20^{\text {th }}$ centuries influenced by William Leche, director of the Hoegskola Zoological Institute in Stockholm. Albertina Carlsson, who was actually born before the middle of the previous century, and Augusta Ärnbäck-Andersson of farming stock in Södermanland, south the capitol, who later married ChristieLind, both contributed to research on small mammals using tooth microfossils [6]. Carlsson taught for many years at Stockholm schools for Girls producing at least 25 papers on fossil canids and relatives. She was awarded an honorary doctorate from Stockholm University in 1927. Christie-Lind intended also to be a teacher but from 1916 became an assistant zoologist and sometimes curator at the national natural history museum.

\section{Romania}

Young Ilona Nopcsa von Felsö-Szilvás, played her part, although not a major role in research; she found dinosaur bones on the family estate at Szentpeterfalva (Sânpetru), Szacsal 'the Land of Hateg'. In 1895, Franz von Nopcsa's sister Ilona was walking along a riverbank near the family home when she found an unusual-looking bone exposed in a hillside; she brought it to her older teenaged brother [6]. The skull turned out to belong to a previously undiscovered Late Cretaceous duck-billed herbivore. The von Nopcsa children were born in Déva, Transylvania, now western Romania into a wealthy noble family, growing up in a provincial backwater of the aging Austro-Hungarian empire. At home, they spoke Hungarian. Franz went on to study Ilona's finds and become a founder of the field of palaeobiology; he died tragically just after Hitler came to power. But what happened to Ilona? How did she fare when communism took over and all the estate was lost in 1920? Based on hers and other dinosaur finds, the Hateg region was trying to become a major geotourism destination in the 2000s, but more recently the Nopsca Szacsal castle was in ruin [14].

\section{Conclusion}

Anyone who has ever got 'hooked' on dinosaurs or mammoths will know the yearning that took over some of the most amazing women of the past 200 years. Many of the early women in the discipline of VP were in Europe and highly constrained by the cultural and political conditions. Here I have brought a 'taste' of several from the early to mid $20^{\text {th }}$ century to the fore; these include pioneers in fish, early tetrapod, dinosaur, dicynodont and early, micro- and Quaternary mammalian studies, as well as in the field of palaeoneurology. Mottl and Steen were not considered by Berta and Turner [6].

Obituaries are rare; only a few, Bate, BrongersmaSanders, Rayner and Edinger have attracted major biographies. Little analysis has been done as yet on the work of others. Most of these early women did not marry or have children - to conduct a life in science meant only one path, and their lives were affected by two world wars. Despite challenges these women paleontologists persisted and went on to become successful scientists! However, by their example, other young women were inspired (including the author) or taught, and by the 1930 s to 1940 s the next cohort were being born or studying and would produce the generational change that included many iconic women in the next era [15]. Their lives-triumphs and challenges-are as diverse and multifaceted as the women. 


\section{International Journal of Paleobiology \& Paleontology}

Although women have made significant progress in STEM fields, they remain underrepresented, including in paleontology; still few are from outside the western world. Even basic facts about their lives are difficult to uncover with lack of obituaries and memorials for earlier women. Change has been slow to overturn what has been a maledominated profession. As with the pioneers, today's women still face challenges - racial and gender equality, ageism, poor mentoring, family issues and sexual harassment. Nevertheless, today around one-third of women scientists are paleontologists; based on our studies, $\sim 17 \%$ of those specialize in VP. The new book Rebels, Scholars \& Explorers will, therefore, be of interest not only to historians of science and current vertebrate palaeontologists but also to the STEM community. In it we have uncovered inspiring stories from more than 1200 women. Participation by women is needed and welcomed in science including VP; by fostering diversity, we ensure that women's contributions are celebrated and future generations passionate about hunting fossil bones encouraged to unravel the history of life.

\section{References}

1. Ogilvie M, Harvey J (2003) The Biographical Dictionary of Women in Science: Pioneering Lives from Ancient Times to the Mid-20th Century. CRC Press.

2. Koelbl Ebert M, Turner S (2017) Towards a history of women in the geosciences. In: Mayer W, Clary RM, Azuela LF, Mota TS, Wołkowicz S, (Eds.), History of Geoscience: Celebrating 50 Years of INHIGEO, Geol Soc, London, SP, 442: 205-216.

3. Oldroyd DR (2002) The Earth Inside and Out. Some major Contributions to Geology in the20th Century. Geol Soc, London 192: 1-16.

4. Falk D (2000) Careers in science offer women an unusual bonus: Immortality. Nature 407(6808): 833.

5. Snyder EE (1940) Snyder, Emily Eveleth. Biology in the Making. McGraw-Hill Book Company, Sci Edu, New York 1-539.
6. Berta A, Turner S (2020) Rebels, Scholars and Explorers: Women in Vertebrate Paleontology. The Johns Hopkins University Press, pp: 1-328.

7. Sharpe $T$ (2020) The Fossil Woman. A Life of Mary Anning. Dovecote Press, UK, pp: 1-240.

8. Schindler K (2004) Discovering Dorothea. The Life of Pioneering Fossil-Hunter Dorothea Bate 1825-1892. Harper Collins Publishers Ltd, London, UK, pp: 1-390.

9. Boylan PJ (2020) Dr Dorothy Helen Rayner FGS (19122003): vertebrate palaeontologist and academic. In: Burek CV, Higgs B, (Eds.), Celebrating 100 Years of Female Fellowship of the Geological Society: Discovering Forgotten Histories, Geol Soc, London, SP: 506.

10. Westoll TS (1958) Studies on Fossil Vertebrates - Essays presented to D.M.S. Watson. Univ of London, Athlone Press, London, pp: 1-263.

11. Milner AC (2016) Lady Smith Woodward's tablecloth. In: Johanson Z, Barrett PM, Richter M, Smith M, (Eds.), Arthur Smith Woodward: His Life and Influence on Modern Vertebrate Palaeontology, Geol Soc, London, SP, 430: 89-111.

12. Jaussaud P, Brygoo ER (2004) Madeleine Friant. In: Jaussaud P, Brygoo ER, (Eds.), Du Jardins au Muséum en 516 Biographies. Muséum national d'Histoire naturelle, France, pp: 231-232.

13. Shipman P (2001) The Man who found the "Missing Link". Eugene Dubois and his lifelong quest to prove Darwin right, Simon Schuster, NY, USA 1-514.

14. Veselka V (2016) History Forgot This Rogue Aristocrat Who Discovered Dinosaurs and Died Penniless. Smithsonian Magazine.

15. Turner S (2020) Far-flung Female (and fossil bone hunting) Fellows: an autoethnographic approach. In: Burek C, Higgs B, (Eds.), Uncovering the historical contribution of women in the Geosciences: Celebrations of first female fellows of GSL, Geol Soc, London, SP: 506.

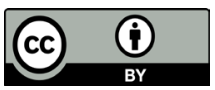

